\title{
EXPANDED CORE CURRICULUM FOR STUDENTS WITH VISUAL IMPAIRMENT
}

\begin{abstract}
Historically, special educators and rehabilitators have found that the traditional curriculum in inclusive schools is not sufficient for students with severe visual impairment. In the educational process, in order to compensate for vision loss, the socalled expanded core curriculum must be included in their education. By applying for this program, students with visual impairment will achieve the same educational outcomes as their sighted peers.

In addition to the traditional school subjects, the expanded core curriculum also provides special subjects for the development of compensatory skills in students with visual impairment. The aim of the program is for students with visual impairments to finish school with the necessary knowledge and skills for independent living. In the system of inclusive education, this program is realized by the special educator and rehabilitator. This paper will explain the components of the expanded core curriculum for students with severe visual impairment.
\end{abstract}

\section{Keywords: EXPANDED CORE CURRICULUM, VISION IMPAIRMENT, INCLUSION}

\section{Introduction}

Globally, the number of students with visual impairment (both those who are blind and those with low vision) in the general education system continues to rise. Visual impairment is commonly known as a "low-incidence" and "high-needs" disability, and, therefore, triggers unique challenges to inclusive schools (Ronal National Institute for the Blind, 2017; Lieberman et al., 2019). "Low incidence disability" means that severe visual impairment is a relatively rare condition among the school-age population. For example, the prevalence of blindness in children ranges from 0.3 per thousand children in developed countries to 1.5 per thousand in developing countries (Bourne et al., 2017). "High needs" is a condition wherein a special educator and rehabilitator are required to regularly support the student in accessing the general education curriculum (Ahsan and Sharma, 2018). Students with severe visual impairment will need to learn braille, Orientation, and Mobility, as well as to use assistive technologies that involve support from qualified teachers for the visually impaired (Miyauchi, 2020). 
Students who are visually impaired require additional knowledge and skills to have equal access to the standard academic curriculum with their sighted peers. To compensate for vision loss their education must incorporate the expanded core curriculum (ECC) (Hatlen, 1996). The goal of ECC (Sapp and Hatlen, 2010), is for children with visual impairments to leave school with the necessary skills to be independent adults.

\section{The ECC}

The expanded core curriculum is a curriculum created specifically for students who are visually impaired, with or without additional disabilities. The ECC provides a framework for instruction in a specialized set of vision-related skills for students with the visually impaired. While students who are visually impaired are expected to follow the same core curriculum as their sighted peers, there are certain areas in which they need specific instruction because of their vision loss.

In inclusive school, all students participate in traditional school's core subjects, such as Language, Math, History, and etc., visually impaired students should also receive additional specific instruction.

According to Sapp and Hatlen (2010), for students with visual impairments, "success in school goes beyond ensuring that students are able to graduate from high school on time" (p. 347). Namely, many concepts and skills that sighted children learn incidentally "must be systematically and sequentially taught" to children with visual impairments (Hatlen, 1996, p. 7). It is the unique developmental needs of these children that led to the formation of the ECC, the framework that guides the education of students with visual impairments (Hatlen, 1996). Because students with visual impairments generally do not learn through visual observation, qualified special educators and rehabilitators must assess these students and provide any needed instruction in all ECC areas (Hatlen, 1996; Sapp and Hatlen, 2010).

First formulated by Hatlen (1996), the ECC refers to the generally accepted nine areas of instruction that children and youths with visual impairments, including those with additional impairments, need to be successful in school, the community, and the workplace. Initially, this program included eight content areas: assistive technology, career education, compensatory access skills, independent living skills, orientation and mobility, recreation and leisure, sensory efficiency skills (previously known as visual efficiency, which includes tactile and auditory skills as well as visual skills), and social interaction skills (Kelly, 2015; Sapp and Hatlen, 2010). For the successful achievement of long-term outcomes by students with visual impairments, in 2003 an additional ninth area was added, the so-called self-determination.

The nine areas of the ECC are those that are typically learned incidentally by sighted children through observing role models. Although children who are visually impaired have little or no opportunity to learn such skills by obser- 
vation, they have the opportunity to acquire them through sequential systematic instruction by a special educator and rehabilitator. Table 1 presents the ECC content areas, the unique needs of students with visual impairments for each area, and examples of skills that need to be developed in these areas.

\section{Table 1.}

Areas of the ECC

\begin{tabular}{|c|c|c|}
\hline Expanded core areas & Unique needs & $\begin{array}{l}\text { Examples of skills and } \\
\text { concepts }\end{array}$ \\
\hline $\begin{array}{l}\text { Compensatory or } \\
\text { access skills }\end{array}$ & $\begin{array}{l}\text { Skills that students with } \\
\text { visual impairment need to } \\
\text { successfully access all areas } \\
\text { of the general education cur- } \\
\text { riculum at a level equitable } \\
\text { to their sighted peers in the } \\
\text { most independent fashion } \\
\text { possible (Sapp and Hatlen, } \\
\text { 2010). }\end{array}$ & $\begin{array}{l}\text { Modes of communication: } \\
\text { listening (audio-books), } \\
\text { speaking (assistive commu- } \\
\text { nication device), writing, } \\
\text { and reading skills (use } \\
\text { print, braille, or tactile } \\
\text { symbols). } \\
\text { Strategies for accessing print- } \\
\text { ed material: reading braille, } \\
\text { using large print, listening } \\
\text { to an audio recording, } \\
\text { having a reader, or use of } \\
\text { an optical device. } \\
\text { Depending on the needs of } \\
\text { the student, compensatory } \\
\text { skills include also study } \\
\text { skills, organizational skills, } \\
\text { and concept development. }\end{array}$ \\
\hline Social interaction & $\begin{array}{l}\text { A big part of communication } \\
\text { is visual - students with } \\
\text { visual impairments may } \\
\text { be less able to observe the } \\
\text { social behavior of others. } \\
\text { Namely, these students can- } \\
\text { not learn social interaction } \\
\text { skills in an incidental way. } \\
\text { So, they need direct instruc- } \\
\text { tions for social interaction } \\
\text { and belonging (Sacks, 2014; } \\
\text { Wolffe and Kelly, 2011). }\end{array}$ & $\begin{array}{l}\text { Social interaction skills are } \\
\text { a very broad category, but } \\
\text { generally include: Con- } \\
\text { versation skills (e.g. ways } \\
\text { to beginning and end a } \\
\text { conversation appropriate- } \\
\text { ly); Nonverbal communication } \\
\text { (e.g. using of facial expres- } \\
\text { sions and body language); } \\
\text { Rules of social interaction } \\
\text { (e.g. rules of physical } \\
\text { contact). }\end{array}$ \\
\hline
\end{tabular}




\begin{tabular}{|c|c|c|}
\hline $\begin{array}{l}\text { Recreational and } \\
\text { leisure }\end{array}$ & $\begin{array}{l}\text { Sighted students select rec- } \\
\text { reational activities in which } \\
\text { to participate by observing a } \\
\text { range of activities and mak- } \\
\text { ing choices. Students with } \\
\text { vision impairment need to } \\
\text { be taught about the activities } \\
\text { available and how to partic- } \\
\text { ipate and become involved } \\
\text { (Sapp and Hatlen, 2010). }\end{array}$ & $\begin{array}{l}\text { These skills must be delib- } \\
\text { erately planned and taught } \\
\text { to students who are visual- } \\
\text { ly impaired. They should } \\
\text { focus on the development } \\
\text { of lifelong skills, for exam- } \\
\text { ple, hobbies, sports, games, } \\
\text { orientation, physical fitness }\end{array}$ \\
\hline Assistive technology & $\begin{array}{l}\text { Assistive technology helps } \\
\text { provide access to inacces- } \\
\text { sible educational material, } \\
\text { equalizing the ability to } \\
\text { access information between } \\
\text { students with vision im- } \\
\text { pairment and their sighted } \\
\text { peers (Brown, Packer, and } \\
\text { Passmore, 2013; Sapp and } \\
\text { Hatlen, 2010). }\end{array}$ & $\begin{array}{l}\text { Technology enhances com- } \\
\text { munication and learning } \\
\text { and expands the world of } \\
\text { persons who are visually } \\
\text { impaired in many ways. } \\
\text { It makes information that } \\
\text { is typically inaccessible } \\
\text { readily available. Students } \\
\text { with visual impairment use } \\
\text { an array of technologies, } \\
\text { for example, computers } \\
\text { with screen enlargement } \\
\text { and screen reading soft- } \\
\text { ware, digital recorders, and } \\
\text { braille writers (Wolffe and } \\
\text { Kelly, 2011). }\end{array}$ \\
\hline
\end{tabular}




\begin{tabular}{|c|c|c|}
\hline $\begin{array}{l}\text { Orientation and mo- } \\
\text { bility (O\&M) }\end{array}$ & $\begin{array}{l}\text { Orientation and mobility } \\
\text { skills are needed for individ- } \\
\text { uals with vision impairment } \\
\text { to safely maneuver in their } \\
\text { environment (Jacobson, } \\
\text { 2012) and involve students } \\
\text { learning about themselves } \\
\text { and the environment in } \\
\text { which they move, from basic } \\
\text { body image to independent } \\
\text { travel (Sapp and Hatlen, } \\
\text { 2010). }\end{array}$ & $\begin{array}{l}\text { O\&M is the set of skills } \\
\text { needed for students, who } \\
\text { are visually impaired to } \\
\text { know where they are in } \\
\text { their environment and } \\
\text { to move safely and inde- } \\
\text { pendently while traveling. } \\
\text { Students learn about them- } \\
\text { selves and their environ- } \\
\text { ments, including home, } \\
\text { school, and community. } \\
\text { O\&M lessons incorporate } \\
\text { skills ranging from basic } \\
\text { body image, spatial rela- } \\
\text { tionships, and purposeful } \\
\text { movement to cane usage, } \\
\text { travel in the community, } \\
\text { and use of public transpor- } \\
\text { tation. Having O\&M skills } \\
\text { enables students to acquire } \\
\text { independence to the great- } \\
\text { est extent possible, based } \\
\text { on their individual needs } \\
\text { and abilities. }\end{array}$ \\
\hline Independent living & $\begin{array}{l}\text { Independent living skills } \\
\text { provide the tools for living } \\
\text { independent adult lives. Al- } \\
\text { though these generally come } \\
\text { easily to sighted individuals, } \\
\text { activities of daily living } \\
\text { including personal hygiene, } \\
\text { food preparation, and } \\
\text { financial management must } \\
\text { be taught to students with } \\
\text { vision impairment (Sapp } \\
\text { and Hatlen, 2010). }\end{array}$ & $\begin{array}{l}\text { This area, often referred } \\
\text { to as daily living skills, } \\
\text { consists of all the tasks } \\
\text { and functions that people } \\
\text { perform, according to } \\
\text { their abilities, to live as } \\
\text { independently as possi- } \\
\text { ble. For example, hygiene, } \\
\text { food preparation, money } \\
\text { management, dressing, } \\
\text { etc. As with the skills of } \\
\text { social interaction, students } \\
\text { who are visually impaired } \\
\text { cannot learn these skills } \\
\text { without direct, sequential } \\
\text { instruction. }\end{array}$ \\
\hline
\end{tabular}




\begin{tabular}{|c|c|c|}
\hline Career education & $\begin{array}{l}\text { Career education in the core } \\
\text { curriculum allows students } \\
\text { to understand different ca- } \\
\text { reer paths. Sighted students } \\
\text { have many opportunities } \\
\text { to learn about careers and } \\
\text { work habits through visual } \\
\text { observation but to compen- } \\
\text { sate for the lack of visual } \\
\text { cues about work and jobs, } \\
\text { students with vision impair- } \\
\text { ment need authentic expe- } \\
\text { riences with various jobs, } \\
\text { which will allow them to } \\
\text { make independent decisions } \\
\text { (Ravenscroft, 2013; Sapp and } \\
\text { Hatlen, 2010; Wolffe and } \\
\text { Kelly, 2011). }\end{array}$ & $\begin{array}{l}\text { Career education for } \\
\text { students with visual im- } \\
\text { pairments needs to begin } \\
\text { as early as possible and } \\
\text { include self-awareness and } \\
\text { career exploration activities, } \\
\text { job-seeking skills instruc- } \\
\text { tion, information about job } \\
\text { keeping, and encourage } \\
\text { opportunities for gaining } \\
\text { work experience. The } \\
\text { students need to gain an } \\
\text { understanding of the many } \\
\text { jobs that are available from } \\
\text { the teacher, to the lower, } \\
\text { to the social worker, to } \\
\text { the artist, to the gardener, } \\
\text { and much much more. The } \\
\text { student who is visually } \\
\text { impaired should have the } \\
\text { opportunity to explore a } \\
\text { wide range of careers in a } \\
\text { systematic, well-planned } \\
\text { manner as they will not be } \\
\text { able to casually observe } \\
\text { these jobs as their sighted } \\
\text { peers can. }\end{array}$ \\
\hline Sensory efficiency & $\begin{array}{l}\text { Sensory efficiency skills refer } \\
\text { to "how well an individual } \\
\text { receives, transmits, and } \\
\text { interprets information about } \\
\text { people, objects, and events } \\
\text { in the environment, using } \\
\text { all sensory systems" (Smith, } \\
\text { 2014, p. 117). } \\
\text { Sensory efficiency addresses } \\
\text { the use of residual vision, } \\
\text { hearing, and other senses, } \\
\text { learning how to use optical } \\
\text { devices, hearing aids, aug- } \\
\text { mentative communication } \\
\text { devices, and other supports } \\
\text { to enable or enhance access } \\
\text { to the environment (Sapp } \\
\text { and Hatlen, 2010). }\end{array}$ & $\begin{array}{l}\text { Individuals with vision } \\
\text { impairments must learn to } \\
\text { access information from the } \\
\text { environment in a somewhat } \\
\text { different way. Therefore, } \\
\text { systematically training } \\
\text { these students to use their } \\
\text { remaining functional vision } \\
\text { and tactile and auditory } \\
\text { senses better and more } \\
\text { efficiently is vital. For ex- } \\
\text { ample, visual, auditory, and } \\
\text { tactile learning: environ- } \\
\text { mental cues and awareness, } \\
\text { personal attributes, sensory } \\
\text { attributes, use of low vision } \\
\text { devices. }\end{array}$ \\
\hline
\end{tabular}




\begin{tabular}{|c|c|c|}
\hline Self-determination & $\begin{array}{l}\text { Self-determination refers to } \\
\text { believing in oneself, under- } \\
\text { standing one's abilities and } \\
\text { limitations, making choices, } \\
\text { and having control over life } \\
\text { experiences (Lieberman et } \\
\text { al., 2014). Namely, self-de- } \\
\text { termination skills have been } \\
\text { related to a student's ability } \\
\text { to explain their vision im- } \\
\text { pairment, self-advocacy, and } \\
\text { ability to accept and decline } \\
\text { help (Agran, Hong, and } \\
\text { Blankenship, 2007). }\end{array}$ & $\begin{array}{l}\text { This area is based on the } \\
\text { premise that students who } \\
\text { are visually impaired must } \\
\text { acquire specific knowledge } \\
\text { and skills and have many } \\
\text { opportunities to practice } \\
\text { them to become successful. } \\
\text { Instruction in the area of } \\
\text { self-determination can } \\
\text { include: Advocate for needs } \\
\text { (explaining their unique } \\
\text { needs); Problem solves (find- } \\
\text { ing solutions of problems); } \\
\text { and Visual impairment } \\
\text { resources (access materials, } \\
\text { resources, and agencies for } \\
\text { people who are visually } \\
\text { impaired). }\end{array}$ \\
\hline
\end{tabular}

\section{Conclusion}

Learning is much more complicated for students with visual impairment (including those with additional disabilities). Because most of these students cannot read or obtain information through the use of vision, they need to learn other skills that enable them to obtain information, such as reading braille or using optical devices that allow them to read print. Skills that are perceived incidentally by sighted students can be completely inaccessible to students who are visually impaired and must be explicitly taught to them in the education process (Willoughby and Duffy, 1989).

All students have the right to quality education, this right is also important for students with severe visual impairment. ECC is a globally recognized prerequisite to the inclusion of students with vision impairment in regular schools. Education of these students should include the traditional core curriculum as well as instruction in areas that are directly affected by a child's vision impairment (Sapp and Hatlen, 2010).

The ECC is not seen as an optional part of a student's with visual impairment educational program but an essential part that must be implemented, compensating for experiences that are typically learned incidentally by sighted children through vision (Lohmeier, Blankenship and Hatlen, 2009). Without training in the ECC skills, students who are visually impaired have difficulty accessing the traditional core curriculum (Allman, Lewis, and Spungin, 2014; Beamish and Brown, 2012). According to Sapp and Hatlen (2010), ECC components in inclusive schools should be taught by certified special educators and rehabilitators. 


\section{References:}

AHSAN, T., SHARMA, U. (2018). Pre-service teachers' attitudes towards inclusion of students with high support needs in regular classrooms in Bangladesh. Br. J. Spec. Educ., 45, pp. 81-97.

AGRAN, M., HONG, S., BLANKENSHIP, K. (2007). Promoting the selfdetermination of students with visual impairments: Reducing the gap between knowledge and practice. Journal of Visual Impairment $\mathcal{E}$ Blindness, 101, pp. 452-464.

ALLMAN, C. B., LEWIS, S., SPUNGIN, S. J. (Eds.). (2014). ECC Essentials: Teaching the expanded core curriculum to students with visual impairments. New York, NY: American Foundation for the Blind.

BEAMISH, W., BROWN, J. E. (2012). The changing role and practice of teachers of students with visual impairments: Practitioners' views from Australia. Journal of Visual Impairment $\mathcal{E}$ Blindness, 106, pp. 81-92.

BOURNE, R. R. A., FLAXMAN, S. R., BRAITHEWAITE, T., CICINELLI, M. V., DAS, A., JONAS, A. B., et al. (2017). Magnitude, temporal trends, and projections of the global prevalence of blindness and distance and near vision impairment: A systematic and meta-analysis. Lancet Glob Health., 5(9), pp. 888-897.

BROWN, C. M., PACKER, T. L., PASSMORE, A. (2013). Adequacy of the regular early education classroom environment for students with visual impairment. The Journal of Special Education, 46(4), pp. 223-232.

HATLEN, P. (1996). The core curriculum for blind and visually impaired students, including those with additional disabilities. RE: view, 28, pp. 25-32.

KELLY, S. M. (2015). Role of vision specialists in special services. In F. E. Obiakor and J. P. Bakken (Eds.), Interdisciplinary connections to special education: Key related professionals involved (Advances in Special Education, Volume 30B) (pp. 197-211). Emerald Group.

LIEBERMAN, L. J., LEPORE, M., LEPORE-STEVENS, M., BALL, L. (2019). Physical education for children. Am. Phys. Educ. Rev., 90, pp. 30-38.

LIEBERMAN, L. J., HAEGELE, J. A., COLUMNA, L., CONROY, P. (2014). How students with visual impairments can learn components of the expanded core curriculum through physical education. Journal of Visual Impairment and Blindness, 108, pp. 239-248.

LOHMEIER, K., BLANKENSHIP, K., HATLEN, P. (2009). Expanded core curriculum: 12 years later. Journal of Visual Impairment $\mathcal{E}$ Blindness, 103, pp. 103-112.

MIYAUCHI, H. (2020). A Systematic Review on Inclusive Education of Students with Visual Impairment. Educ. Sci., 10, pp. 346.

RAVENSCROFT, J. (2013). High attainment low employment: The how and why educational professionals are failing children with visual impairment. The International Journal of Learning, 18, pp. 135-144. 
RONAL NATIONAL INSTITUTE FOR THE BLIND. (2017). Children and Young People-England. London, UK: RNIB Evidence-Based Review.

SACKS, S. Z. (2014). Social interaction. In C. B. Allman and S. Lewis (Eds.), ECC Essentials: Teaching the expanded core curriculum to students with visual impairments (pp. 324-368). New York, NY: AFB Press.

SAPP, W., HATLEN, P. (2010). The expanded core curriculum: Where we have been, where we are going, and how we can get there. Journal of Visual Impairment $\mathcal{E}$ Blindness, 104, pp. 338-348.

SMITH, M. (2014). Sensory Efficiency. In C. B. Allman, S. Lewis, S. J. Spungin, (Eds.). ECC essentials: Teaching the expanded core curriculum to students with visual impairments (pp. 117-186). New York, NY: AFB Press.

WILLOUGHBY, D. M. (1989). Two representatives of many successful blind teachers. In D. M. Willoughby, S. L. M. Duffy, (Eds.). Handbook for itinerant and resource teachers of the blind and visually impaired (p. 413). Baltimore, MD: National Federation of the Blind.

WOLFFE, K. E., KELLY, S. M. (2011). Instruction in areas of the expanded core curriculum linked to transition outcomes for students with visual impairments. Journal of Visual Impairment E Blindness, 105, pp. 340-349. 
